\title{
Formulation of New Autonomic Regional Policy Making Process
}

\author{
(Case Study in Sofifi City, North Maluku)
}

\author{
Andy Fefta Wijaya* \\ Department of Public Administration, Faculty of \\ Administrative Sciences \\ University of Brawijaya \\ Malang, Indonesia \\ *andyfefta@ub.ac.id
}

\author{
Darwin Abd Radjak, Sumartono, M. R. Khairul Muluk \\ Public Administration, Faculty of Administrative Sciences \\ University of Brawijaya \\ Malang, Indonesia
}

\begin{abstract}
The process of forming an autonomous region is inseparable from the spatial pattern of socio-economic life because this is a major consideration in determining regional boundaries. The relationship of social and economic interaction in people's daily lives. The problem faced is the regional boundaries, lack of attention from local governments on social life, a sense of political identity and the efficiency of public services. The purpose of this study is to describe and analyse the formation of autonomous regions needed in Sofifi city. The research used is a qualitative approach with a Spiral data analysis model from Creswell. This research was conducted in Sofifi City, North Maluku. The source of research data obtained from local governments and community leaders in the Sofifi city. Internal documents in the form of memos, announcements, instructions, rules of a particular community institution that is used within the community itself or as an institution. External documents contain information material produced by a social institution, such as magazines, bulletins, statements, and news that are broadcast to the mass media. Photos, videos, and other research documentation. Those are the condition of the discatchment area or the low reach of institutions and government officials in the Tidore Islands to the people in the four sub-districts, both in the North Oba District, Middle of Oba District, Oba District and South Oba District. This is what causes the community to have the desire that Sofifi City be immediately established as the New Autonomous Region. Those are the formation of a new autonomous region Sofifi City can provide opportunities for regional development, which is in the four Districts in the Oba region and accelerate competitiveness in the area of expansion and increase the competitiveness of the economy in the sub-districts that enter the new region formation area. Sofifi city is carried out based on 3 aspects of the structuring of autonomous regions namely spatial patterns of socioeconomic life, a sense of political identity, efficiency of public services, these three aspects are the reasons for the Sofifi City's autonomous region to be formed.
\end{abstract}

Keywords-formulation, policy, autonomous region, sofifi

\section{INTRODUCTION}

The implementation of regional government on the basis of regional autonomy is a form of public awareness as the holder of the actual autonomy rights to manage their households based on the authority that has been given by the central government in a broad, real, and responsible manner. Regional autonomy must be interpreted as a way to achieve prosperity at the local level, not as a result of work achieved by local governments. Regional autonomy belongs to the community. The surrender of authority from the community to the regional government to implement regional autonomy philosophically was because the regional government was formed based on the principles of democracy by the people [1].

Autonomy also contained system integrity, in the sense of having boundaries. Therefore, autonomy also has an identity. In other words, there was no autonomy if there were no boundaries. Determination of these limits was reminiscent of an overall system. Following that idea, autonomy in the autonomous region, which was self-contained has activity boundaries, that were actually and functionally agreed upon and integrated with an environment that received outputs and provides inputs [2].

The implementation of regional autonomy that puts forward the concept of decentralization, is expected to provide a double benefit. On the one hand, the region is free from pressures and interventions from the central government so that regional initiatives and creativity can develop. In other words, the region will experience a significant empowerment process, so that it is increasingly able to deal with various regional problems. The granting of authority to the regions to regulate and manage their regions can spur the regions in exploring the potential of the regions to increase their sources of income. On the other hand, the central government is free from unnecessary burdens in handling regional affairs, and subsequently is able to concentrate on the formulation of strategic national and global macro policies [3]. 
Decentralization as the transfer of authority, responsibility, and resources through deconcentration, delegation, or devolution from the centre to the lower administrative level, by Rondinelli and Cheema [4]. According to Syaukani et al [5], of course, the choice of decentralization must be based on strong argumentation both theoretically and empirically. With various problems faced in adopting and realizing a federalistic government, then as an alternative is to choose the form of the Unitary State by organizing government on the basis of the principles of decentralization, which involves the relationship of power with all its dimensions between the National government and the Regional Government. According to Rondinelli and Cheema [4], decentralization has a meaning that can be seen holistically or narrowly which is defined as follows: Decentralization is the transfer of planning, decision making or authority from the administration of the central government to the organizations below it, as well as local administrative units, semi-autonomous organizations and local government or non-government organizations.

Some problems faced in the formation of new regions, among others, were conveyed by Djojosoekarto and Harjanto 2008 as quoted by Prasojo et al [6] in his book entitled Impacts and Problems in the Administration of the New Autonomous Region, due to several factors include: First, the wide scope of service areas, Second, ease of enlargement or regional formation requirements, Third, encouragement of financial and political impacts of enlargement, Fourth, lack of local government attention in the provision of public services, Fifth, religious and cultural differences resulting in disharmony in society, the Sixth, socio-cultural and historical factors

The Ministry of Public Works and Public Housing (PWPH) through the Regional Infrastructure Development Agency is pushing for the acceleration of the development of Sofifi New City in North Maluku. "In the 2015-2019 National Medium Term Development Plan, Sofifi is one of 10 new public cities that are planned to develop. Supporting the development of Sofifi New City, the Ministry of PWPH has programmed various Public Works and Public Housing infrastructure development programs, including the management of the Galala and Bukit Durian Village plantations. "There is also an environmental drainage development program. In addition, there is the construction of a glorious embung in Sofifi Village, construction of bathing, washing, latrine facilities in North Oba District, provision of village clean water pipes, improvement of the road network to the Sofifi Collecting Port. Then, the prevention and improvement program for slums, the construction of self-help housing, the construction of special fishing houses, the construction program for break water construction or the security of the Guraping Coastline. "Construction of bore wells in Bukit Duri Subdistrict, Sofifi City Drinking Water Supply System development program, and construction of the Final Waste Disposal Site in Kaiyasa Village. According to Mudrajad Kuncoro, the development of Sofifi New City is an opportunity for regional governments to be able to improve the quality and equity of economic growth, improve quality and create equitable economic growth that will be effective in reducing poverty, unemployment, and inequality of people's welfare. Thus, the development of Sofifi New City can be utilized optimally [7].

The purpose of this study is to describe and analyse the formation of autonomous regions.

\section{Methods}

This study uses a qualitative approach. The researcher makes a complex tunnel, examines words, detailed reports from the respondents' views and conducts studies in natural situations. The research is conducted in the Sofifi City, North Maluku. The people in the region who are directly related to the readiness of the government in the formation of the Sofifi City autonomous region which is planned to carry out this research and documented activities through photographs or video recordings and documents in the study location. Data analysis was performed descriptively using a spiral analysis model adapted from Creswell [8].

\section{LITERATURE REVIEW}

\section{A. The Role of Actors in Regional Autonomy}

The success or failure of various fields of national life is increasingly determined by regional performance, because with regional autonomy most of the responsibilities and tasks of government have been handed over to the region, particularly the regency or city, Zuhro [9]. For this reason, the study of the role of actors in the process of local democracy in the era of regional autonomy is important to remember since there are two things: First, in relation to local political culture, actors are cultural agencies. As a cultural agency, on the one hand the actor as a successor to the values of political culture that grows and develops in the local shutter. In other words, the role of actors is one of the important keys to the success of democracy because the behaviour of actors and the resulting policies have an important meaning and also have a significant effect on the consolidation of democracy. Second, in relation to democracy, the political transition process that took place in Indonesia in the last ten years has provided a forum, as well as placing the actors, both at the national and local levels. In a different political context from previous eras, Zuhro [9].

According to Zuhro [10], basically a theory that emphasizes the importance of the role of the elite is rooted in the following thoughts: First, the key actors in the transition process are the political elite in governance and opposition. Second, these actors are typically distinguished according to their orientation towards regime change, such as extreme moderates and according to interests rooted in economic structure and conditions and their institutional role. Third, these actors acted strategically as influenced by their level of assessment of competitors and their allies. Fourth, democracy is the result of elite negotiations, both explicitly and implicitly.

By borrowing the framework of Tornquist, Linz, Stephan, and Diamond, that interaction between the factors can be seen in two main arenas, namely: first, the interaction of the respective divisions (micro politics), second, the interaction 
between the factors in a wider arena (macro politics). One important arena that can be used to further see the involvement of actors in the broader arena is the process of political competition and public policy making. Interactor interaction also takes place in the arena of political competition where actors in the political community contest in winning elected positions. In the process of the competition, political actors (politicians and political parties) meet, touch and build networks with other actors, such as a small and economic society. For this reason, it can be seen that the policy-making process can be seen through several sides by looking at the chord of interventions and their importance [10].

\section{B. Regional Government Bureaucracy}

Government bureaucracy carried out by bureaucrats must always lead to the interests of society. power that has been in the hands of bureaucrats must shift its locus to the community because everything that becomes and is made by the bureaucrats is sourced from the aspirations, needs, and interests of the community. What is not important for the community is that the bureaucrat is aware of where he must act and behave by using the authority and power of the state, and if he must act as a servant and servant of the community, who must not show an attitude of playing only strength and power. Conceptually, according to the bureaucracy is an organization that is shown to maximize efficiency in administration which, according to Sayre, has the following characteristics: Specialization of duties, hierarchy of authorities, statutory bodies, reporting systems and personnel with special skills and roles, Blau (1963) as quoted by Sinambela [11].

According to Said [12] that the essence of bureaucracy is the clarity of duties and authority, impersonality where people must follow the rules, not the rules to follow people's tastes. Bureaucracy is also directly related to efficiency, productivity, organizational system, and implementation of government and of course, this can be considered as tools or tools to pursue justice for the maximum number of citizens. In the world of government, the concept of bureaucracy is interpreted as a process and system that is created rationally to guarantee the mechanism and system of work that is regulated, certain and easily controlled. In language, the term bureaucracy comes from French, bureau which means office or desk, and the Greek word, kratein which means to regulate. "Bureaucracy refers to a particular form and style of administrative organization. Although it has been subject to strong criticism for a long time, bureaucracy and its variants can still be found in a large number of organizations" (Peter M. Blau and Marshal W. Meer).

\section{Decentralization and Regional Autonomy}

Decentralization has changed rapidly over the past few centuries along with the evolution in thinking about governance. Until the early 1980s and the state generally felt in turn. The government is seen as an embodiment of state sovereignty institutions and as a dominant source of political and legal decision making. In developing countries, debates over the structure, role and functions of government are focused on the effectiveness of central power and authority in promoting economic, social, potential advantages and disadvantages of decentralizing authority to the state. In essence decentralization is the autonomization of a society that is in a certain territory. As an emission of understanding the sovereignty of the people, of course the autonomy is given by the Government to the community and not at all to the region or the Regional Government. The firmness of the statement of autonomy belonging to the community and the community as a subject and not an object of autonomy needs to be declared in the future to align the implementation of regional autonomy [2].

According to Abdul Wahab et al [13], in the political literature, specifically about the dynamics of political life and local government (including the concept of regional autonomy associated with the concept of decentralization), the cross will be placed in the corridor of a tradition of polyarchical political thought, namely a tradition of thought that gives appreciation high on the freedom of space for society, for the development of alternative thinking, and for the presence of relatively independent political units outside the state complex.

However, decentralization in a government organization has become a universally accepted principle. Decentralization is the legal conferring of powers to discharge specified or residual functions upon formally constituted local authorities (the conferring of legal powers to carry out certain functions or residuals against local authorities that are formally established). Decentralization is an instrument used to achieve certain goals. The objectives of the implementation of decentralization can be in the form of national unity, democratic governance, independence as an embodiment of autonomy, efficient administration, and socio-economic development Maddick, Hoessein [2,6].

According to Santoso [14], the implementation of decentralization can co-exist with a centralized deconcentration, considering the diversity of the entire territory of the country and the desire to provide the broadest opportunities for the regions in developing and developing regional progress in all fields including human resources. Thus, all regions throughout Indonesia are able to develop independently and remain framed within the Unitary State of the Republic of Indonesia, so that it is necessary to build a new government that is more appropriate, that is, decentralization which has a core or relies on autonomy.

The complexity of the concept of decentralization in general can be categorized into two main perspectives, namely Political decentralization perspective and administrative decentralization perspective. The political decentralization perspective defines decentralization as the devolution of power from the central government to regional governments. The administrative decentralization perspective emphasizes the definition of decentralization as a delegation of administrative authority from the central government to regional governments. This was also said by Rondinelli [4], as quoted by Muluk [15], 
administrative decentralization can also be used to exercise state control over regional units in order to increase greater political participation in decision making [15].

\section{RESULTS AND DisCUSSION}

\section{A. Spatial Patterns of Socio-Economic Life}

Basically, the process of forming a new autonomous region cannot be separated from the spatial pattern of socio-economic life because this is the main consideration in determining regional boundaries. The relationship between social and economic interactions in the daily life of the people in the four sub-districts, including North Oba District, Central Oba District, Oba District and South Oba District, are quite good. The determination of regional boundaries is a very important factor in determining the existence of a spatial pattern of socioeconomic life in the sub-districts that enters the formation of new autonomous regions.

According to the informant namely The Head of North Oba Sub-District, Mr. SG, when the researcher asked about the spatial pattern of socio-economic life in the process of forming a new autonomous region, said that:

"In the socio-economic life of the people in the North Oba District seen in social interaction and developments that occur in the community in North Oba and changes in the community increased socially and economically this is one of our hopes because in my opinion this greatly affects regional boundaries, social relations and interactions between fellow daily life are very strong, tolerance and mutual cooperation are well maintained. (Interview, July 5th, 2018).

Besides that, in line with the reality above, the researcher conducted interviews with other informants related to the reasons for the new autonomous region in the spatial pattern of socioeconomic life, namely The Head of Sofifi Sub-District, Mr. BA, this informant stated that:

"The pattern of socioeconomic life in Sofifi has a strong influence on the plan for the formation of a new autonomous region, in this Sofifi region the socioeconomic level in the community has begun to be good even though it is not in line with what is expected but at least there are few changes. makes us here have a high sense of concern and our social interaction is maintained. Then we see from the social characteristics and economic characteristics that have begun to shift to the service sector, one of which is this mode of transportation utilized by the Soffi community, for us this greatly affects the regional boundaries in the process of forming the city of Sofifi. (Interview, July 11th, 2018).

The two informants above have the same understanding of social interactions and economic interactions with the spatial patterns of social and economic life in the formation of a new area. For those, the patterns that have been formed from in accordance with social characteristics and economic characteristics so far are still able to maintain and even improve their lives both in the social and economic fields. By the formation of this new autonomous region, it can bring a change to the social and economic aspects because this is one of the main considerations in determining regional boundaries. Their social life remains strong. The community is always compact doing things that can create solidarity, establish good relations with other people, and help each other.

The socio-economic life of the community and the condition of its territory which consists of the sea and islands, hills, and tropical forests. Therefore, the pattern of community life such as farming, trading really colours the dynamics of socio-economic life among the special community in Sofifi City and the people of North Maluku in general. For this reason, the current motto that becomes the motto of the North Maluku Provincial Government, namely Marimoi Ngone Futuru, Masidika Ngone Foruru (united, we steadfastly divorced, we collapse), is an invitation to maintain solidarity and participation. This cultural potential is the most valuable development capital to be developed in the development of Sofifi City area.

The main role of Sofifi city as a maritime centre in the Sofifi-Ternate-Tidore Cluster as the basis for the vision of Sofifi city as a centre for maritime economic development. The maritime sector as the main production potential of areas other than plantations needs to be developed and improved in value and production results. By the aim of improving the welfare of local communities as well as empowering it in the maritime field (Source: Sofifi New City Master Plan, North Maluku 2015-2045, Ministry of PPN / Bappenas).

\section{B. Political Identity}

The aspect of political identity from the desire to form a new autonomous region can be seen that the dynamics of political identity that occur in the region itself. This is directly related to the desire of the community to obtain wider authority in the administration of regional government. Conditions like this are needed a sense of unity of political identity in the formation of the new autonomous region of Sofifi City. The sense of political identity in the four sub-districts namely North Oba District, Central Oba District, Oba District and South Oba District, that are included in the Tidore Islands City area, this is a very important factor in determining regional boundaries. for this reason, the people in the four sub-districts become a political entity. Important factors that must be seen are religion, ethnicity, and culture that develops and is sensitive so that demands arise to form new autonomous regions.

According to the informant namely the Chairman of the Regional House of Representatives Tidore Islands City, Mr. AA. SE, when the researcher asked about political identity in the process of forming new autonomous regions, said that:

"The desire to form a new autonomous region of Sofifi City is a desire of all the people in the 4 (four) districts, namely North Oba District, Middle Oba District, Oba District and South Oba District because they feel they have the same political unity. Therefore, community participation in political 
identity is very important for the people in the district" (Interview, July 25th, 2018).

Then the researcher also conducted interviews with other informants related to a sense of political identity in the process of forming a new autonomous region namely Deputy Chairman of Commission III of the Tidore Islands City Representative Council, Mr. AK. This informant said that:

"People in the mainland oba, in terms of ethnicity, religion, have the potential to be a challenge in the process of forming a new autonomous region of Sofifi City, differences in religion, ethnicity and ethnicity that are in the community in an administrative area, becoming one wish in the community existing on the mainland oba to separate themselves from the parent region, the government and related ranks must be sad to see this, because political identity is very important and we must understand, this is often conveyed to my friends in the council, because if not noticed with both it will be an injustice in politics, social and economic inequality. "(Interview, June 26th, 2018).

For this reason, the two informants have the same understanding that political identity in the process of forming a new autonomous region, is a strong effort from the people in the four sub-districts, North Oba District, Central Oba District, Oba District and South Oba Subdistrict to separate from the main city, namely the City of Tidore Islands, because what has been felt so far in the sense of political identity is less felt. The size of the area and the number of populations that causes a community representation is very lacking in policy making. This causes them to feel marginalized, so they submit demands that the formation of a new autonomous region be formed so that they have representation on the policy making process. Community efforts in four sub-districts namely North Oba Subdistrict, Central Oba Subdistrict, Oba Subdistrict and South Oba Subdistrict, to continue to push Sofifi City to become the New Autonomous Region.

The capital of North Maluku in Sofifi, is a small town located in the archipelago and its position is on the west coast of Halmahera, opposite the City of Tidore Islands. For this reason, Sofifi City is located in the North Oba District, Sofifi City is very strategically surrounded by Tidore City, Ternate City and Halmahera Island. Sofifi's historical development since the reign of Sultan Zainal Abidin Syah. Sofifi's readiness as a development city by locating local transmigration originating from Tidore Island and the Tobaru tribe community (interior of Halmahera) and sanger tribes scattered on the Halmahera coast. For this reason, the formation of a new autonomous region can exert influence and form aspirations and wishes of the community in the area to become a new autonomous region, through a mechanism that has been determined by the applicable law.

\section{Efficiency of Public Services}

After understanding holistically about the formation of a new autonomous region, Sofifi City of North Maluku which is in accordance with the mandate of Law Number 46 Year 1999 which states that the Capital City of North Maluku is domiciled in Sofifi. For this reason, it is related to the welfare of the people in the Oba plains area, North Oba District, Central Oba Subdistrict, Oba Subdistrict and South Oba Subdistrict, but the efficiency of public services felt by the people in the four Subdistricts are not so good. In the formation of a new autonomous region, there are various aspects that determine the aspects of geography, administrative aspects, economic and social politics. However, the demand for the establishment of new autonomous regions desired by the people in the Sofifi region itself is because there are hidden reasons since the Sofifi city wants to expand, including the longing for public services to the community such as Family Cards and other administrative arrangements. Sofifi City itself not the same as Tidore Islands City, which means administration of residents, the people in the four Districts themselves must cross the sea to go to Tidore City as the main city, because Sofifi itself is still included in the Tidore Islands City government area.

Basically, in the process of forming this new autonomy region, it can have a positive impact in improving public services in accordance with the wishes of the people who are in the four Districts, be it North Oba District, Central Oba District, Oba District and South Oba District. In the demand for the establishment of a new autonomous region, is to open access to public services that often experience obstacles, in Government Regulation No. 78 Year 2007, it has been emphasized that improving the welfare of the community through improving services to the community, accelerating the growth of democratic life, accelerating the implementation of regional economic development, accelerating managing regional potentials, enhancing security and order as well as enhancing good relations between the centre and the regions. In all service activities carried out by public service providers in an effort to meet the needs of service recipients as well as implementation in accordance with existing rules, which have been set by the central and regional governments. In the standard public service delivery duly pay attention to service standards which are a guarantee in certainty for service recipients because a standard of public service must have a patented measure in the administration of the service itself.

According to the informant, namely the Head of Oba District, Mr. IAR. When the researchers asked about the reasons for the efficiency of public services, said that:

"In the public service that natural communities are quite difficult because the people themselves if they want to deal, they have to go to the Tidore Islands City by crossing the ocean, it is not certain that in one day immediately so even they have to wait for days such as the management of birth certificates and other arrangements. Because of its reach, it makes it difficult for the community to take care of their administrative needs. We hope that Sofifi City will soon be established as a new autonomous region so that we people on the mainland oba, so that public services can run optimally ". (Interview, IAR December 10th, 2017). 
The information provided by IAR, shows that the public services in the Oba area are inefficient, this is also due to the inadequate facilities in the oba area so that it indirectly forces the community to take care of themselves. For this reason, the Establishment of the Sofifi City Autonomous Region has been able to meet the needs of public services to the community in North Oba District, Central Oba District, Oba District and South Oba District. In essence, in the delivery of public services in this area the Tidore Islands City government must be obliged and responsible in providing efficient and effective services to the people in the four sub-districts in accordance with public service standards.

\section{CONCLUSION}

Based on the discussion above, it can be concluded that the determinants of the regional autonomy structuring aspects have the main goal of which is for accelerating the achievement of social and economic welfare levels of the community, meeting the needs of public services and the formation of new autonomy can influence and form aspirations and desires of the community in four sub-districts namely the District North Oba, Central Oba District, Oba District and Oba District.

\section{REFERENCES}

[1] H. Sabarno, Untaian Pemikiran Otonomi Daerah Memandu Otonomi Daerah Menjaga Kesatuan Bangsa. Jakarta: Sinar Grafika, 2008.

[2] B. Hoessein, Perubahan model, pola, dan bentuk pemerintahan daerah dari era Orde Baru ke era reformasi. Depok: Departemen Ilmu
Administrasi, Fakultas Ilmu Sosial dan Ilmu Politik, Universitas Indonesia, 2011.

[3] S.H. Sarundajang, Babak baru sistim [ie sistem] pemerintahan. Jakarta: Hasta Word Library, 2012.

[4] G.S. Cheema and D.A. Rondinelli, Decentralizing governance: emerging concepts and practices. Washington: Brookings Institution Press, 2007.

[5] H.R. Syaukani, A. Gaffar and M.R. Rasyid, Otonomi daerah dalam negara kesatuan. Kerjasama Pustaka Pelajar [dan] Pusat Pengkajian Etika Politik dan Pemerintahan, 2002.

[6] E. Prasojo, Impacts and Problems in the Administration of the New Autonomous Region. Depok: UI Press, 2012.

[7] BPIW, bpiw-pacu-percepatan-pengembangan-kota-baru-sofifi [Online] Retrieved from: bpiw.pu.go.id/article/detail/bpiw-pacu-percepatanpengembangan-kota-baru-sofifi. Acessed on 04 November 2017.

[8] J.W. Creswell, Qualitative Inquiry \& Research Design Choosing Among Five Approaches. California: Sage Publication.

[9] R.S. Zuhro, Local Democracy, The Role of Actors in Democratization. Yogyakarta: Ombak.

[10] R.S. Zuhro, Local Democracy Models, East Java, West Sumatra, South Sulawesi, and Bali. Jakarta: The Habibie Center.

[11] L.P. Sinambela, Public Service Reform: Theory, Policy, and Implementation. Reformasi Pelayanan Publik: Teori. Jakarta: Bumi Aksara.

[12] M.M. Said, Bureaucracy in a Bureaucratic Country, Its Meanings Problems and Deconstruction of the Indonesian Bureaucracy. UMM Press, 2012.

[13] S. Abdul Wahab, The Future of Regional Autonomy "Social, Economic and Political Studies to Create Synergies in Regional Development. Publisher: SIC, 2002.

[14] H.M.A. Santoso, Responding to the Regional Autonomy Screen in Indonesia. Yogyakarta: Student Library, 2013.

[15] M.R.K. Muluk, Decentralization \& Regional Government Concept Map. Surabaya: ITS Press, 2009. 